OPEN ACCESS

Edited by:

Nicolas Fanin,

INRA Centre

Bordeaux-Aquitaine, France

Reviewed by:

Xiangzhong Luo,

Lawrence Berkeley National Laboratory, United States Frances Claire Manning, University of Aberdeen, United Kingdom

*Correspondence: Emma J. Sayer e.sayer@/ancaster.ac.uk

Specialty section: This article was submitted to Tropical Forests,

a section of the journal Frontiers in Forests and Global

Change

Received: 31 August 2019 Accepted: 18 December 2019

Published: 14 January 2020

Citation:

Kerdraon D, Drewer J, Chung AYC, Majalap N, Slade EM, Bréchet L.

Wallwork $A$, Castro-Trujillo $B$ and Sayer EJ (2020) Litter Inputs, but Not

Litter Diversity, Maintain Soil

Processes in Degraded Tropical Forests-A Cross-Continental

Comparison.

Front. For. Glob. Change 2:90 doi: 10.3389/ffgc.2019.00090

\section{Litter Inputs, but Not Litter Diversity, Maintain Soil Processes in Degraded Tropical Forests - A Cross-Continental Comparison}

\author{
Deirdre Kerdraon ${ }^{1}$, Julia Drewer ${ }^{2}$, Arthur Y. C. Chung ${ }^{3}$, Noreen Majalap ${ }^{3}$, \\ Eleanor M. Slade ${ }^{1,4,5}$, Laëtitia Bréchet ${ }^{1,6,7}$, Abby Wallwork ${ }^{1,2}$, Biancolini Castro-Trujillo ${ }^{8}$ and \\ Emma J. Sayer ${ }^{1,8 *}$ \\ ${ }^{1}$ Lancaster Environment Centre, Lancaster University, Lancaster, United Kingdom, ${ }^{2}$ Centre for Ecology and Hydrology, \\ Penicuik, United Kingdom, ${ }^{3}$ Sabah Forestry Department, Forest Research Centre, Sandakan, Malaysia, ${ }^{4}$ Department of \\ Zoology, University of Oxford, Oxford, United Kingdom, ${ }^{5}$ Asian School of the Environment, Nanyang Technological University, \\ Singapore, Singapore, ${ }^{6}$ Department of Biology, Centre of Excellence PLECO (Plant and Ecosystems), University of Antwerp, \\ Wirijk, Belgium, ${ }^{7}$ INRA, UMR Ecology of Guiana Forests (EcoFoG), AgroParisTech, Cirad, CNRS, Université des Antilles, \\ Université de Guyane, Kourou, French Guiana, ${ }^{8}$ Smithsonian Tropical Research Institute, Balboa, Panama
}

Land-use change in tropical forests can reduce biodiversity and ecosystem carbon (C) storage, but although changes in aboveground biomass $\mathrm{C}$ in human-modified tropical forests are well-documented, patterns in the dynamics and storage of $\mathrm{C}$ belowground are less well characterised. To address this, we used a reciprocal litter transplant experiment to assess litter decomposition and soil respiration under distinct litter types in forested or converted habitats in Panama, Central America, and in Sabah, Malaysian Borneo. The converted habitats comprised a large clearing on the Panama Canal and oil palm plantation in Borneo; forested habitats comprised a 60-year old secondary forest in Panama and a disturbed forest in Borneo that was selectively logged until 2008. In each habitat, we installed mesocosms and litterbags with litter collected from old-growth forest, secondary forest or an introduced species: Elaeis guineensis in Borneo and Saccharum spontaneum in Panama. We measured litter mass loss, soil respiration, and soil microbial biomass during nine months at each site. Decomposition differed markedly between habitat types and between forest vs. introduced litter, but the decay rates and properties of old-growth and secondary forest litters in the forest habitats were remarkably similar, even across continents. Slower decomposition of all litter types in the converted habitats was largely explained by microclimate, but the faster decay of introduced litter was linked to lower lignin content compared to the forest litter. Despite marked differences in litter properties and decomposition, there was no effect of litter type on soil respiration or microbial biomass. However, regardless of location, litter type, and differences in soil characteristics, we measured a similar decline in microbial activity and biomass in the absence of litter inputs. Interestingly, whereas microbial biomass and soil respiration increased substantially in response to litter inputs in the forested habitats and the converted habitat in Panama, there was little or no corresponding 
increase in the converted habitat in Borneo, indicating that soil recovery capacity had declined substantially in oil palm plantations. Overall, our results suggest that litter inputs are essential to preserve key soil processes, but litter diversity may be less important, especially in highly disturbed habitats.

Keywords: litter decomposition, litter traits, soil microbial biomass, soil respiration, plant-soil interactions, secondary tropical forest, land-use change, forest conversion

\section{INTRODUCTION}

Intact tropical forests are one of the largest terrestrial carbon $(\mathrm{C})$ sinks; they sequester an estimated $1.1 \pm 0.3 \mathrm{Pg} \mathrm{C} \mathrm{y}^{-1}$ (Malhi, 2010) and tropical forests contain c. 55\% of the terrestrial organic C stock (Pan et al., 2011), making them an essential part of the global $\mathrm{C}$ balance. However, disturbance from anthropogenic activity is jeopardising the $\mathrm{C}$ sink potential of tropical forests (Lal, 2005; Don et al., 2011; Dent et al., 2013; Laurance et al., 2014). Worldwide, tropical deforestation is responsible for the release of $1.7 \mathrm{Pg} \mathrm{C}$ per year and logging and land cover change are responsible for $25 \%$ of anthropogenic carbon dioxide $\left(\mathrm{CO}_{2}\right)$ emissions (Le Quéré et al., 2018); in 2014, deforestation and forest degradation were responsible for tree cover loss amounting to 24 million hectares (Global Forest Watch, 2018). Between 2000 and 2005, widespread forest degradation turned tropical forests into C sources instead of sinks (Bruun et al., 2009; Malhi, 2010; Dent et al., 2013; Laurance et al., 2014) and degraded or secondary forests now represent $60 \%$ of tropical rainforests (Hansen et al., 2013; Laurance et al., 2014). Forest degradation and conversion also affect carbon storage belowground: direct conversion from primary forest to agricultural land results in losses of $20-30 \%$ of soil organic carbon (SOC) and secondary forests store an estimated $9 \%$ less $\mathrm{C}$ in soils than primary forests (Don et al., 2011), which is cause for concern as tropical forests contain c. 30\% of the global soil C stocks (Stockmann et al., 2013). Currently the main drivers of tropical deforestation are cattle ranching, forestry products, oil palm, soya plantations, and cereal crops (Pendrill et al., 2019). The drivers of tropical deforestation and forest degradation differ by region. For example in Central and South America, conversion to pastures plays a key role (Armenteras et al., 2017), whereas in Southeast Asia, most of the degradation happens because of conversion of forest to croplands (Reynolds et al., 2011; Wilcove et al., 2013), in particular oil palm plantations.

A substantial amount of $\mathrm{C}$ in tropical forests is stored belowground and the conversion of forest to non-forested landuse can dramatically reduce belowground C stocks (Scharlemann et al., 2014). During forest conversion, soil disturbance releases stored $\mathrm{C}$ as $\mathrm{CO}_{2}$ to the atmosphere, and soil $\mathrm{C}$ is also lost through increased surface run off and erosion with reduced vegetative cover (Guillaume et al., 2015; Tesfaye et al., 2016). The lack of a closed canopy in converted habitats also reduces plant $\mathrm{C}$ inputs and alters the microclimate at the forest floor, which can limit decomposition processes (Lorenzo et al., 2014) and soil C storage (Powers, 2004). Forest disturbance can also alter soil $\mathrm{C}$ dynamics and storage by modifying the microclimate and tree community composition. Undisturbed old-growth tropical forests are generally characterised by slow-growing plant species that are more shade-tolerant and have greater belowground biomass and structural stability (Dent et al., 2013). By contrast, young secondary forests are composed primarily of pioneer tree species that are fast-growing, tolerant to sunlight and have high foliar nutrient concentrations that are better adapted to the drier microclimate (Swaine and Whitmore, 1988). Aboveground woody biomass in the secondary forests of Sabah, Malaysia, is only one third that of the old-growth forest (Riutta et al., 2018) and greater canopy openness after disturbance increases the amount of direct sunlight reaching the understorey, which in turn increases the variation in air and soil temperature, as well as soil water content (Dechert et al., 2004; Wright, 2005; Houghton, 2012). Such changes in species composition and the abiotic conditions on the forest floor will affect the decomposition processes underpinning soil $\mathrm{C}$ dynamics and storage by altering the quality and quantity of plant litter inputs and the environment for microbial decomposers.

Litterfall is one of the most important sources of organic matter in forest ecosystems and plays a key role in $\mathrm{C}$ and nutrient cycling (Vitousek, 1984; Attiwill and Adams, 1993; Adachi et al., 2006; Sayer and Tanner, 2010). Litter inputs provide resources to soil microbial decomposers and, during decomposition, plantavailable nutrients such as nitrogen $(\mathrm{N})$ are released and organic C is stored in the soil (Gougoulias et al., 2014). Lower soil microbial activity has been linked to decreases in sources of organic matter and declines in aboveground plant diversity (Van Der Heijden et al., 2008). These interactions between plants and soil organisms are a key part of the soil $\mathrm{C}$ cycle. Changes in the properties of the litter could affect the ability of the soil microbes to decompose the litter. However, it is not clear how changes in the nature of the organic matter provided to the microbes affects them and their C cycling abilities (Hättenschwiler et al., 2005; Fanin et al., 2011; Marichal et al., 2011). Therefore, we should seek to understand if and how degradation of forest habitats affects carbon cycling in the tropics, so that action can be taken to increase their sustainability.

Understanding the functional interactions between plant litter inputs and soil processes that control soil $\mathrm{C}$ storage is essential to determine the links between changes in biodiversity and ecosystem function (Isbell et al., 2011; Handa et al., 2014), such as C accumulation and retention during forest degradation. Many decomposition studies have been carried out using litterbags with specific litter mixtures from chosen plant species (Hättenschwiler et al., 2005, 2011). Such standardised litter mixtures can be broadly representative of temperate forests with low species diversity, but this approach is less appropriate for capturing the high diversity of tropical forests 
(Hättenschwiler et al., 2005). Furthermore, although soil $\mathrm{CO}_{2}$ efflux is commonly used to assess microbial activity in different habitats, very few field studies in tropical forests have combined controlled decomposition experiments with measurements of $\mathrm{CO}_{2}$ efflux to assess whether soil or litter characteristics are the main drivers of litter decomposition (Ayres et al., 2009). In this context, mesocosm experiments are a useful tool because they allow targeted experimental manipulations under field environmental conditions while minimising soil disturbance (Laird-Hopkins et al., 2017). Hence, mesocosms can be used to measure $\mathrm{CO}_{2}$ efflux (i.e., soil respiration) over the soil and decomposing litter mixtures to assess the relative importance of soil properties and leaf litter composition (Ayres et al., 2009) for soil microbial activity.

We established a cross-continental mesocosm experiment under field conditions to assess the effect of plant litter and soil properties on soil $\mathrm{C}$ dynamics and decomposition processes in the tropics. The experiment aimed to identify general patterns on two different continents, which have experienced high rates of deforestation: one study site was located in the Stability of Altered Forest Ecosystems (SAFE) project in Sabah, Malaysian Borneo (Ewers et al., 2011) and the other in the Barro Colorado National Monument (BCNM) in Panama. At each site, the mesocosm experiment used reciprocal litter treatments to establish how different litter mixtures, representing varying degrees of forest degradation, affect soil $\mathrm{C}$ dynamics in forested and converted habitats. We aimed to test the following hypotheses:

1) Soil microbial activity (decomposition and soil respiration) will be lower in the converted than the forest habitats as a result of a more exposed environment, which creates microclimatic conditions unfavourable to decomposition.

2) After accounting for microclimate, the differences in litter decomposition, soil respiration, and microbial biomass among sites and experimental treatments will be attributable to differences in litter properties and soil organic matter content.

3) Due to the low inputs of plant material to the soil in converted habitats, litter treatments will have a relatively greater influence on soil respiration and microbial biomass in converted habitats compared to forest habitats.

\section{METHODS}

\section{Study Sites and Habitats}

To assess common patterns in different tropical regions, we conducted our study at two experimental field sites, one in Sabah, Malaysian Borneo and one in Panama, Central America. The climate in Malaysian Borneo is wet tropical with average monthly rainfall of $164.1 \pm 24.34 \mathrm{~mm}$, which mainly falls during the wet season from November to March, and there is a mild dry season from April to October; average monthly temperature is $32.5 \pm$ $0.67^{\circ} \mathrm{C}^{1}$. The soils at the study site are classed as Ultisols (USDA classification; Riutta et al., 2018).

The climate in Panama is classed as wet tropical with average monthly rainfall of $213 \pm 52.8 \mathrm{~mm}$, most of

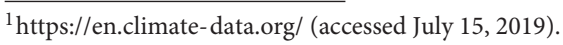

which falls during the rainy season between April and November and a dry season from December to March; average monthly temperature is $25.8 \pm 0.5^{\circ} \mathrm{C}^{1}$. The soil at the study sites is classed as an Oxisol (USDA classification) with a $\mathrm{pH}$ of 4.5-5.0 and low phosphorus availability (Sayer and Tanner, 2010; Wright et al., 2011).

The experiments each lasted nine months and were carried out over two years: the Malaysian experiment was set up in March 2015 and the Panamanian experiment started in October 2016. The specific climate conditions during the experimental period at each study site are summarised in Table $\mathbf{1}$.

In Malaysia, our experiment was conducted within the SAFE project in Sabah, Malaysian Borneo, which was designed as a long-term landscape-scale experiment to assess changes in biodiversity and ecosystem function as a result of anthropogenic activity (Ewers et al., 2011). The SAFE project covers an area of 32 $\mathrm{km}^{2}$ including secondary forest, watersheds and first generation oil palm plantations between 10 and 17 years old. In Panama, the experiment was set-up within the Barro Colorado Nature Monument (BCNM), administered by the Smithsonian Tropical Research Institute. The BCNM covers $47 \mathrm{~km}^{2}$ and includes oldgrowth forest, secondary forest in various stages of regeneration, as well as disturbed habitats and grassland along the banks of the Panama Canal. The study sites are henceforth referred to as SAFE and BCNM.

Our experiments focused on two habitats types: forest habitat and converted habitat. At SAFE, the forest habitat was a hardwood forest that was partially logged in the 1970s, and again between 1990 and 2008 (Ewers et al., 2011; Riutta et al., 2018), and the converted habitat consisted of oil palm plantations planted in 1998, 2001, and 2005; the palm fronds in the oil palm plantations are placed in piles in systematic locations as opposed to layered over the soil surface like natural litterfall from trees. At BCNM, the equivalent habitats were a 60 year-old secondary forest growing on previously cultivated land and the converted habitat was a clearing on the edge of Gatun Lake, part of the Panama

TABLE 1 | Comparison of study sites for a mesocosm experiment comparing soil properties, litter decomposition, and soil respiration in forested and converted sites in Malaysian Borneo and Panama, Central America, where SAFE is the Stability of Altered Forest Ecosystems project in Malaysian Borneo and BCNM is the Barro Colorado Nature Monument in Panama.

\begin{tabular}{lccc}
\hline & & Malaysian Borneo (SAFE) & Panama (BCNM) \\
\hline Coordinates & & $4^{\circ} 66^{\prime} \mathrm{N} 117^{\circ} 56^{\prime} \mathrm{E}$ & $9^{\circ} 11^{\prime} \mathrm{N} 79^{\circ} 82^{\prime} \mathrm{W}$ \\
Soil type (USDA) & Ultisols & Oxisol \\
Soil pH & $4.0-6.5$ & $4.5-5.0$ \\
Study period & & Mar-Nov 2015 & Oct $2016-\mathrm{Jun} 2017$ \\
Air temperature & Mean & $28.1 \pm 0.2^{\circ} \mathrm{C}$ & $26.9 \pm 0.7^{\circ} \mathrm{C}$ \\
& Min. & $22.4^{\circ} \mathrm{C}$ & $22.8^{\circ} \mathrm{C}$ \\
& Max. & $38.3^{\circ} \mathrm{C}$ & $31.0^{\circ} \mathrm{C}$ \\
Monthly rainfall $(\mathrm{mm})$ & Mean & $164.1 \pm 24.3 \mathrm{~mm}$ & $231.0 \pm 89.7 \mathrm{~mm}$ \\
& Min. & $45.0 \mathrm{~mm}$ & $8.6 \mathrm{~mm}$ \\
& Max. & $343.0 \mathrm{~mm}$ & $835.9 \mathrm{~mm}$
\end{tabular}


Canal, that has been maintained as grassland by mowing since the 1960s.

\section{Experimental Design}

We assessed the influence of litter type on litter decomposition and soil respiration at both sites and habitats using an in situ mesocosm experiment with four litter treatments: old-growth (primary) forest litter, secondary forest litter, introduced litter, and a bare soil control with no litter inputs (Figure 1).

For the SAFE experiments, the old-growth forest litter was collected from Maliau Basin (intact primary forest) the secondary forest litter was collected from the study sites in logged forest, and the introduced litter was oil palm fronds (Elaeis guineensis Jacq.), a palm species from western Africa. At BCNM, the oldgrowth forest litter was collected from nearby $>300$-year old forest, the secondary forest litter was collected from the 60 year old forest at the study site and the introduced litter was wild sugar cane (Saccharum spontaneum L.), which originates from Asia and is found in open and disturbed habitats along the Panama Canal. Freshly fallen litter at each forest site was collected from the surface of the litter layer, whereas introduced litter was cut from the plants according to common site management practices. All litter types were air-dried to constant weight at $40^{\circ} \mathrm{C}$.

In each habitat, we established six blocks of mesocosms. The mesocosms were made of PVC pipe $(20 \mathrm{~cm}$ diameter and $13 \mathrm{~cm}$ length), sunk into the ground to $3 \mathrm{~cm}$ depth; all mesocosms were placed at least $1 \mathrm{~m}$ away from trees and $1.5 \mathrm{~m}$ away from palms. Each block consisted of one mesocosm for each of the four treatments to allow for destructive sampling after 9 months. Consequently, the experiment comprised 96 mesocosms in total $(2$ sites $\times 2$ habitats $\times 6$ blocks $\times 4$ treatments; Figure 1). Each mesocosm received $16 \mathrm{~g}$ of litter, the equivalent of the mean litter standing crop in the forest sites in SAFE, which was calculated from six samples collected close to the experimental blocks in the forest sites.

We measured decomposition rates using litterbags containing $16 \mathrm{~g}$ of each litter mixture. The bags were made of $1.4 \mathrm{~mm}$ mesh and measured $18 \times 18 \mathrm{~cm}$ to give an equivalent surface area to the mesocosms. At both sites, two bags of each litter type were placed in each replicate block and one bag of each litter type was harvested from each block after six and nine months, giving 144 bags in total $(2$ sites $\times 2$ habitats $\times 6$ blocks $\times 3$ treatments $\times 2$ timepoints). The litter was carefully removed from the bags and gently rinsed under running water to remove soil particles; the samples were then dried to constant weight at $40^{\circ} \mathrm{C}$ and weighed to determine mass loss.

\section{Field Measurements}

Soil respiration (i.e., $\mathrm{CO}_{2}$ efflux) was measured monthly over the mesocosms using an infrared gas analyser with a soil chamber attachment. At SAFE the measurements were taken with an EGM-4 infrared gas analyser and an SRC-1 soil chamber (PP systems, Amesbury, USA), using a custom-made adaptor $(20 \mathrm{~cm}$ diameter and $5 \mathrm{~cm}$ height). At BCNM we used a Li8100 soil survey system with a $20 \mathrm{~cm}$ Survey Chamber (Li-Cor Biosciences, Lincoln, Nebraska, USA). The two systems give highly comparable values for soil respiration with similar errors (Pumpanen et al., 2004). At both sites, soil temperature and soil water content were recorded during each soil $\mathrm{CO}_{2}$ efflux measurement c. $0.5 \mathrm{~m}$ from the mesocosm; soil temperature was measured at $0-10 \mathrm{~cm}$ depth using a traceable thermometer (Fisherbrand, Hampton, FL, USA) and soil water content was measured at $0-6 \mathrm{~cm}$ depth using a soil moisture sensor, with

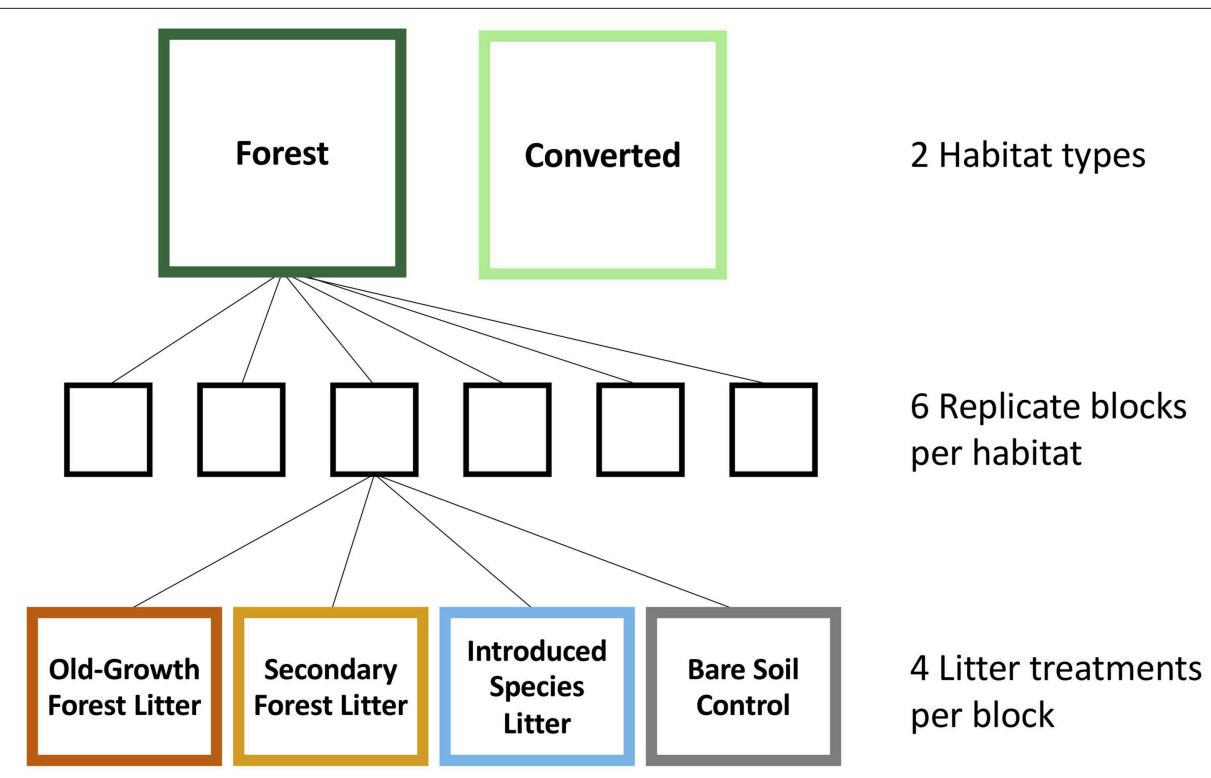

FIGURE 1 | Schematic diagram illustrating the set-up of a mesocosm experiment carried out in Malaysia and Panama, showing the two habitat types: forest and converted habitat, the six replicate blocks and the four litter treatments: old-growth forest, secondary forest, introduced species, and no litter (bare soil control). 
general mineral soil calibration (SM150T, Delta-T Devices, Cambridge, UK).

To characterise the soils at each site, we collected five soil cores from each block at the start of the experiments in March 2015 (SAFE) and November 2016 (BCNM). The soil cores were mixed to form one composite sample per block, air-dried at $40^{\circ} \mathrm{C}$, and then stored in resealable polyethylene bags until chemical analysis. To assess changes in soil properties after nine months, we collected two soil cores from the centre of the mesocosm and composited them to give one replicate sample per block, treatment, and habitat. All soil samples were collected at 0$10 \mathrm{~cm}$ using a $3-\mathrm{cm}$ diameter punch corer. Samples for analysis of soil microbial biomass were refrigerated for seven days. The remaining material was air-dried at $40^{\circ} \mathrm{C}$. Subsamples of dried soil and litter were subsequently ground with a ball mill (Mixer Mill 400, Retsch, Haan, Germany) for chemical analyses.

\section{Laboratory Analyses}

Total $\mathrm{C}$ and $\mathrm{N}$ in litter and soil samples were analysed by high temperature combustion gas chromatography (Vario El III C/N analyser, Elementar, Stockport, UK) using $30 \mathrm{mg}$ of soil and $15 \mathrm{mg}$ of litter. Soil extractable phosphorus (P) and potassium (K) were analysed by spectrometry after extraction using the modified Morgan's method, and litter P, K, calcium (Ca), and magnesium $(\mathrm{Mg})$ concentrations nutrients were analysed by ICP-OES spectrometry after nitric acid digest at a commercial laboratory (SAC consulting, SRUC, Aberdeen, Scotland).

We determined microbial biomass $\mathrm{C}$ and $\mathrm{N}$ after fumigation extraction (Vance et al., 1987 with modifications by Jones and Willett, 2006) using paired 8-g subsamples of fresh soil. Briefly, one subsample per pair was fumigated with ethanolfree amylene-stabilised chloroform for $24 \mathrm{~h}$ and both subsamples were then extracted with $40 \mathrm{~mL} 0.5 \mathrm{M} \mathrm{K}_{2} \mathrm{SO}_{4}$, centrifuged and filtered through pre-washed filter paper (Whatman $42^{\circledR}$ or equivalent). The extracts were analysed for total organic $\mathrm{C}$ and total $\mathrm{N}$ by combustion after nine-fold dilution (TOC-L combustion analyser coupled with a TNM-L unit, Shimadzu Corp, Kyoto, Japan). Microbial biomass $\mathrm{C}$ and $\mathrm{N}$ were calculated from the difference between non-fumigated and fumigated samples without correction.

We determined acid detergent fibre (ADF) and lignin (ADL) in litter samples by hot extraction (Van Soest et al., 1991) in two steps using a fibre analysis system (Fibertec ${ }^{\mathrm{TM}}$ 8000, FOSS, Hilleroed Denmark). To measure ADF, the litter samples (1 $\mathrm{g}$ dry weight) were placed in a glass crucible with $1 \mathrm{~g}$ of celite and the samples were washed in boiling acid detergent solution for $1 \mathrm{~h}$, rinsed with deionised water $\left(\mathrm{dH}_{2} \mathrm{O}\right)$, soaked in acetone for $5 \mathrm{~min}$, and drained. The samples were dried at $105^{\circ} \mathrm{C}$ for $12 \mathrm{~h}$ and then weighed; total ADF was calculated by subtracting the weight of the remaining material from the original sample weight (after correction with blanks). To determine acid detergent lignin (ADL), the material remaining after ADF extraction was soaked in $\mathrm{H}_{2} \mathrm{SO}_{4}$ for $3 \mathrm{~h}$ and washed with hot $\mathrm{dH}_{2} \mathrm{O}$ until acid-free. The remaining material was dried at $105^{\circ} \mathrm{C}$ for at least $5 \mathrm{~h}$ and then ashed in a furnace at $525^{\circ} \mathrm{C}$ for $3 \mathrm{~h}$. The lignin content (ADL) was calculated by subtracting the final weight of the sample from the weight of total extracted fibre (ADF) (after correction with blanks).

\section{Data Analysis}

We calculated the litter decay rate $(k)$ for each litter type, habitat and site according to Olson (1963) (Equation 1):

$$
\ln \left(\frac{X}{X_{0}}\right)=-k t
$$

where: $t$ is time in years since the bags were placed in the field, $X_{0}$ is the initial litter dry mass and $X$ is litter dry mass at collection.

We used log response ratios (RR) to the calculate effect sizes for the litter treatments and make direct comparisons of soil respiration and soil microbial biomass between sites and habitats. We calculated the RR for soil respiration for each litter treatment per block and month and the RR for soil microbial biomass per block at the end of the experiment using Equation (2):

$$
R R=\ln \left(\frac{R_{x}}{R_{c t}}\right)
$$

where $R_{x}$ is the value in litter treatment and $R_{c t}$ is the value from the corresponding bare soil control.

All statistical analyses were conducted in $\mathrm{R}$ version 3.5.1 ( $\mathrm{R}$ Core Team, 2018) using the lme4 package for linear mixed effects models (Bates et al., 2014). Data were transformed where necessary to meet modelling assumptions. We used linear models ( $m$ function) to assess differences among habitats in initial soil properties, the influence of litter treatment and habitat on litter decay rates and microbial biomass, and the relationships between soil respiration, microbial biomass, and litter decay rates. We assessed the influence of specific litter properties on decay rates across all litter types and both locations using linear regressions; visual inspection of the data revealed that many litter properties were correlated and we thus selected properties known to influence decomposition in tropical forests (lignin, $\mathrm{N}$, $\mathrm{P}$, and $\mathrm{K}$ content). We assessed the effects of habitat and litter treatment on soil respiration, temperature and water content, as well as the RR of soil respiration using linear mixed effects models (lmer function) with habitat, litter treatment, site and their interactions as fixed effects, and block and month as random effects. The minimum adequate model was identified by sequentially dropping terms, using AIC and $p$-values to check for model improvement (Pinheiro and Bates, 2000). The final models were compared to appropriate null models using likelihood ratio tests and the model fit was assessed using diagnostic plots (Crawley, 2007). Where we found no effects of individual litter treatments, we conducted a second set of analyses assessing the general influence of litter inputs on soil respiration and microbial biomass in the different habitats by comparing the mean values across all litter treatments to the bare soil controls.

For linear models, we give the F-statistic with degrees of freedom, and for linear mixed effects models we give the chisquared $\left(\chi^{2}\right)$ value for the comparison to the relevant null model. We report significant terms at $p<0.01$ and marginally significant trends at $p<0.1$. 


\section{RESULTS}

\section{Soil and Litter Properties}

Although soil properties differed between sites (Table 2), there were no general trends in soil properties among habitats. At BCNM, total soil $\mathrm{C}$ and $\mathrm{N}$ content in the forest habitat were significantly higher than in the converted habitat, with almost twice the amount of $\mathrm{C}$ and $\mathrm{N}$ at $0-10 \mathrm{~cm}$ depth, but there were no differences in soil $\mathrm{C}$ and $\mathrm{N}$ content among habitats at SAFE (Table 2). The models that best explained total soil $\mathrm{C}$ and $\mathrm{N}$ included habitat, country and their interaction [Soil C: $F_{(3,20)}$ $=32.13, p<0.001$; soil $\left.\mathrm{N}: F_{(3,20)}=23.87, p<0.001\right]$. There was no significant difference between habitats for extractable $\mathrm{P}$, extractable $\mathrm{K}$ or soil $\mathrm{pH}$ at either site (Table 2).

The forest litters were similar between forest types and sites. By contrast, although the introduced litters had similar C content across sites, the introduced litter at SAFE had nearly double the $\mathrm{N}$ content of the introduced litter at BCNM and the lignin: $\mathrm{N}$ ratio was more than twice as high (Table 3). The forest litter had slightly higher $\mathrm{C}$ content than introduced litter at BCNM but not at SAFE (Table 3). However, the lignin content and lignin: $\mathrm{N}$ ratios of the forest litters were substantially higher than the introduced species at both sites (Table 3). The $\mathrm{P}$ content of the introduced litter was almost twice as high as the forest litter at both sites, whereas the $\mathrm{K}$ content of introduced litter was higher than the forest litter at BCNM, but not at SAFE. Decay rates increased with litter $\mathrm{P}\left(R^{2}=0.59, p=0.045\right)$ and litter $\mathrm{K}$ content $\left(R^{2}=0.73, p=0.019\right)$ but decreased with increasing lignin content $\left(R^{2}=0.84, p=0.006\right)$ and the lignin: $\mathrm{N}$ ratio best explained litter decay rates $\left(R^{2}=0.86\right.$, $p=0.005$; Table 3 ).

Regardless of litter type, litter decomposition was significantly slower in the converted habitat than in the forest habitat at both sites (Figure 2). The decay rate $k$ of the litter types reflected the differences in litter properties between introduced and forest litter: the introduced litters $(k=1.93 \pm 0.24$ at SAFE and 2.83 \pm 0.22 at $\mathrm{BCNM})$ decomposed faster than the forest litters $(k$ $=0.93 \pm 0.13$ at SAFE and $1.12 \pm 0.11$ at $\mathrm{BCNM}$ ) regardless of habitat. Overall, litter decay rates were higher at BCNM than SAFE (Table 2) and hence, the model that best explained the decay rate included country, litter type and habitat, but not their interactions $\left[F_{(4,61)}=35.4, p<0.001\right]$.

\section{Soil Respiration and Microbial Biomass}

Soil respiration was significantly higher in the forest habitats than the converted habitats at both sites (Figure 3). Although soil respiration from the mesocosms was higher in all litter treatments compared to the bare soil controls, there were no significant differences in respiration among litter types (Supplementary Table S1; Supplementary Figure S1). Subsequent comparison of mesocosms with and without litter inputs revealed significantly higher soil respiration in the mesocosms with litter compared to bare soil in both habitats and at both sites, although soil respiration from the litter treatments at BCNM was lower than the controls during the dry season (months 4-7, Figure 3). The final model for soil respiration therefore included habitat, litter input and their interaction $\left(\chi^{2}=49.16, p<0.001\right)$.

Microbial biomass $\mathrm{C}$ and $\mathrm{N}$ were significantly greater in BCNM than in SAFE regardless of habitat (Figure 4; Supplementary Table S2). At both sites, microbial biomass C was significantly higher in the forest habitat (SAFE: $121 \pm 16$ $\mu \mathrm{g} \mathrm{g}^{-1}$ and BCNM: $443 \pm 18 \mu \mathrm{g} \mathrm{g}^{-1}$ ) than in the converted habitat (SAFE: $65 \pm 10 \mu \mathrm{g} \mathrm{g}^{-1}$ and BCNM: $186 \pm 15 \mu \mathrm{g} \mathrm{g}^{-1}$ ). There was no discernible effect of individual litter treatments, as microbial biomass did not differ among mesocosms containing introduced litter or forest litter (Supplementary Figure S2). The mesocosms with litter inputs had greater microbial biomass $\mathrm{C}$ than the bare soil controls in the converted habitat at BCNM (Figure 5). The model that best explained microbial biomass $C$ therefore included litter input, habitat, site and the site $\times$ habitat interaction $\left[F_{(5,71)}=16.53, p<0.001\right]$. Microbial biomass $\mathrm{N}$ was also significantly higher in the forest habitats than the converted habitats but there was no influence of litter treatments or litter inputs (Figure 5). The model that best explained microbial biomass $\mathrm{N}$ therefore included only habitat and site $\left[F_{(6,79)}=79.92, p<0.001\right]$. Analysis of the response ratios (RR) for soil respiration and microbial biomass revealed that, contrary to our third hypothesis, the response of soil respiration to litter inputs was smaller in the

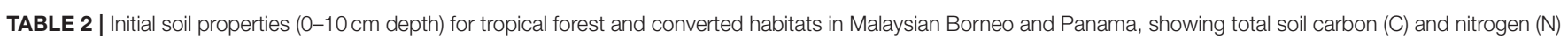
concentrations, extractable phosphorus (P), and potassium (K) and soil pH, and soil C to N (C:N) ratios, where SAFE is the Stability of Altered Forest Ecosystems Project in Sabah, Malaysian Borneo and BCNM is the Barro Colorado National Monument, Panama, Central America; means \pm standard errors are shown for $n=6$; different superscript letters denote significant differences between habitat types at $p<0.05$.

\begin{tabular}{|c|c|c|c|c|}
\hline & \multicolumn{2}{|c|}{ Forest habitat } & \multicolumn{2}{|c|}{ Converted habitat } \\
\hline & Malaysia (SAFE) & Panama (BCNM) & Malaysia (SAFE) & Panama (BCNM) \\
\hline Soil pH & $4.98( \pm 0.42)$ & $5.12 \pm 0.10$ & $4.77 \pm 0.19$ & $5.42 \pm 0.29$ \\
\hline Total C (\% dry weight) & $1.44( \pm 0.15)$ & $5.67 \pm 0.23^{a}$ & $1.88 \pm 0.50$ & $3.03 \pm 0.36^{b}$ \\
\hline Total N (\% dry weight) & $0.25( \pm 0.01)$ & $0.57 \pm 0.03^{a}$ & $0.31 \pm 0.03$ & $0.04 \pm 0.04^{b}$ \\
\hline C:N & $5.72( \pm 0.48)$ & $10.03 \pm 0.32$ & $5.73 \pm 0.97$ & $10.04 \pm 1.14$ \\
\hline Extractable P $\left(\mathrm{mg} \mathrm{kg}^{-1}\right)$ & $5.73( \pm 1.97)$ & $4.89 \pm 0.78$ & $6.58 \pm 2.71$ & $4.30 \pm 0.88$ \\
\hline Extractable $\mathrm{K}\left(\mathrm{mg} \mathrm{kg}^{-1}\right)$ & $595.18( \pm 179.42)$ & $804.64 \pm 133.75$ & $456 \pm 58.9$ & $748.48 \pm 143.59$ \\
\hline
\end{tabular}


TABLE 3 | Characteristics of leaf litter from forest habitats or introduced species used in parallel litter decomposition experiments at SAFE in Malaysian Borneo and BCNM in Panama, showing litter carbon $(\mathrm{C})$ and nitrogen $(\mathrm{N})$ content, carbon to nitrogen ratio (C:N), phosphorus (P), potassium (K), calcium $($ Ca), magnesium (Mg), total fibre and lignin content, and lignin to nitrogen ratio (lignin:N); chemical analyses were conducted on composite litter samples and mean decay rates were calculated for each litter type across all habitats; percentages are given on a dry mass basis.

\begin{tabular}{|c|c|c|c|c|c|c|}
\hline \multirow{2}{*}{$\frac{\text { Litter type }}{\text { Property/Site }}$} & \multicolumn{2}{|c|}{ Introduced } & \multicolumn{2}{|c|}{ Secondary forest } & \multicolumn{2}{|c|}{ Primary forest } \\
\hline & SAFE & BCNM & SAFE & BCNM & SAFE & BCNM \\
\hline Decay rate $(k)$ & $1.93 \pm 0.2$ & $2.83 \pm 0.2$ & $0.96 \pm 0.2$ & $1.11 \pm 0.1$ & $0.91 \pm 0.2$ & $1.14 \pm 0.1$ \\
\hline C (\%) & 44.7 & 45.3 & 44.7 & 49.2 & 46.3 & 49.9 \\
\hline N (\%) & 1.89 & 1.15 & 1.17 & 1.30 & 1.38 & 1.80 \\
\hline C:N ratio & 23.6 & 39.2 & 38.2 & 37.2 & 33.5 & 27.4 \\
\hline $\mathrm{P}(\%)$ & 0.13 & 0.11 & 0.06 & 0.05 & 0.06 & 0.06 \\
\hline K (\%) & 0.86 & 1.38 & 0.76 & 0.34 & 0.27 & 0.26 \\
\hline Fibre (\%) & 19.6 & 22.0 & 31.4 & 32.3 & 35.3 & 33.0 \\
\hline Lignin (\%) & 4.97 & 1.53 & 17.21 & 16.90 & 17.50 & 21.00 \\
\hline Lignin:N & 2.63 & 1.33 & 14.7 & 13.0 & 12.7 & 11.7 \\
\hline Lignin:P & 38.2 & 13.9 & 277.5 & 318.9 & 301.7 & 333.3 \\
\hline $\mathrm{Ca}(\%)$ & 0.62 & 0.38 & 0.66 & 1.28 & 1.26 & 1.56 \\
\hline $\mathrm{Mg}(\%)$ & 0.37 & 0.13 & 0.26 & 0.25 & 0.29 & 0.27 \\
\hline $\mathrm{Zn}\left(\mathrm{mg} \mathrm{kg}^{-1}\right)$ & 19.3 & 29.2 & 19.0 & 32.0 & 18.7 & 40.5 \\
\hline
\end{tabular}

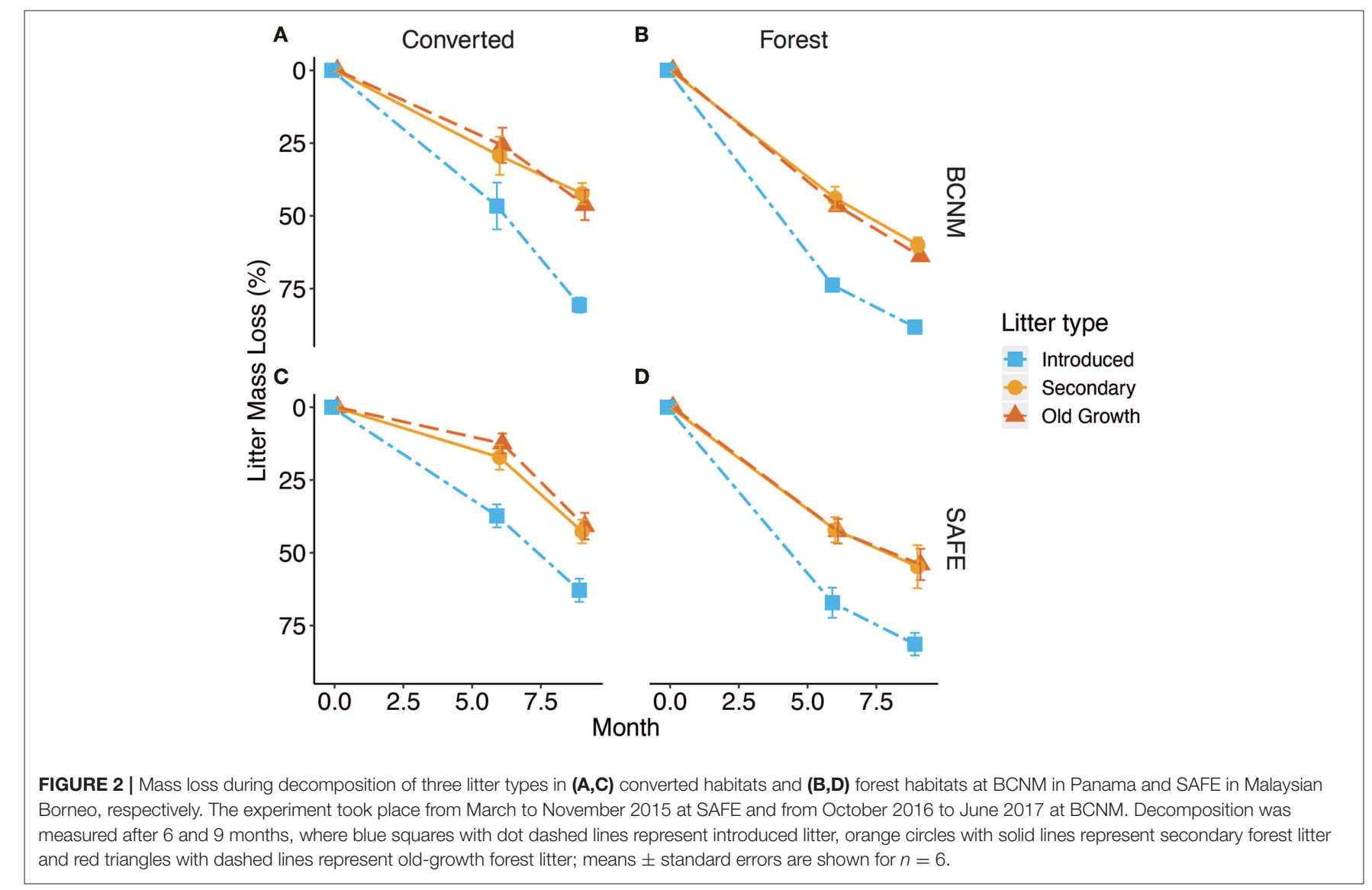

converted than the forest habitats across both sites $\left(\chi^{2}=6.23\right.$, $p=0.012$ ) and there was no difference in the response of soil microbial biomass to litter inputs between converted and forest habitats.
Across sites and habitats, there was no relationship between litter decomposition and soil respiration or microbial biomass but mean soil respiration increased with microbial biomass $C\left(R^{2}\right.$ $=0.91, p<0.001)$ and $\mathrm{N}\left(R^{2}=0.92, p<0.001\right.$; Figure 5). 

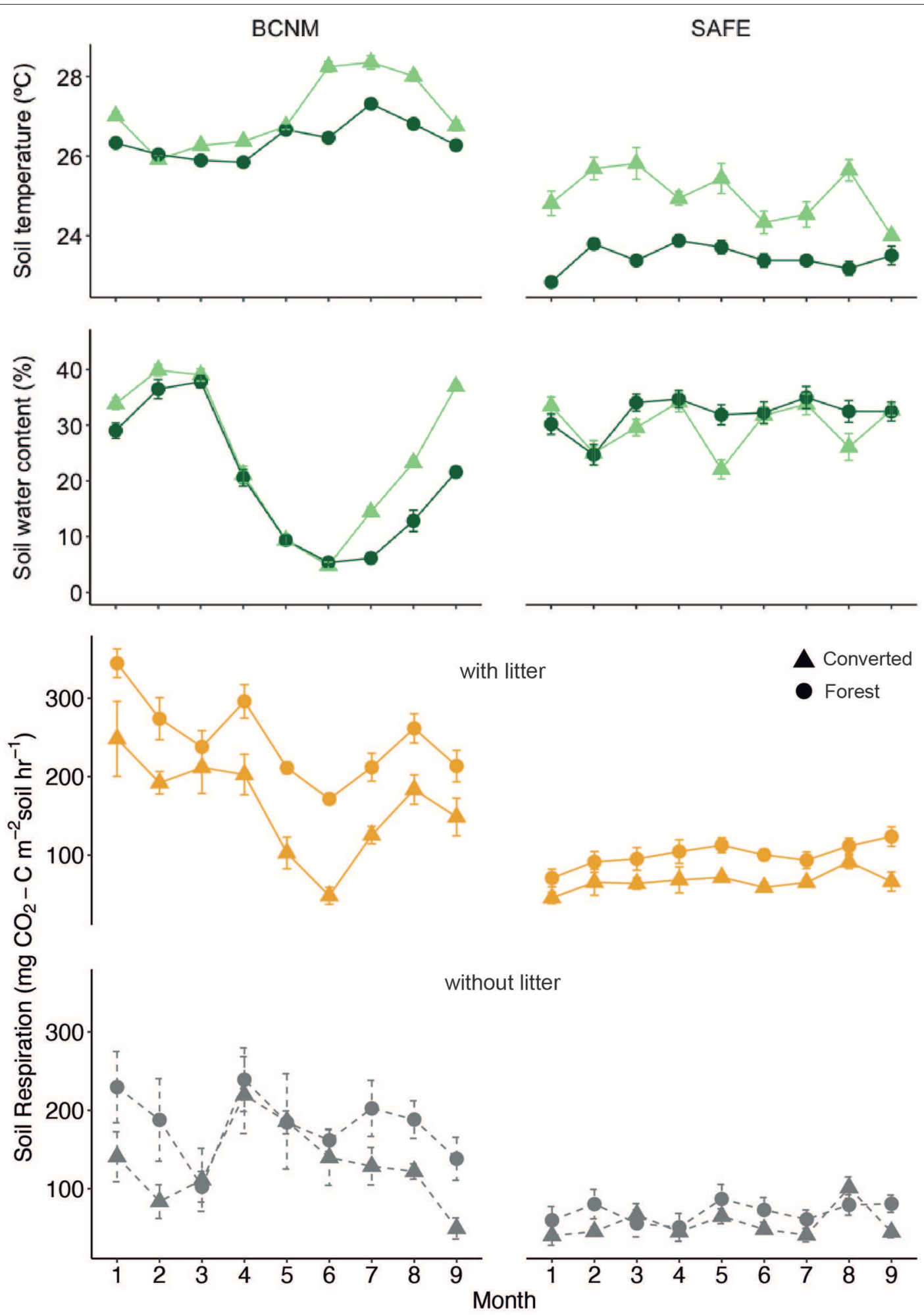

FIGURE 3 | Patterns of soil temperature (top panel), soil water content (second panel) and soil respiration ( $\mathrm{CO}_{2}$ efflux; bottom panels) in tropical forest (circles) or converted habitats (triangles) at SAFE in BCNM in Panama and at SAFE in Malaysian Borneo; soil respiration was measured over mesocosms with litter inputs (orange solid lines) and without litter (grey dashed lines). The experiment took place from March to November 2015 at SAFE and from October 2016 to June 2017 at BCNM; means and standard errors are shown for $n=24$ per time point for soil temperature and soil water content, and for $n=6$ per time point for soil respiration. 


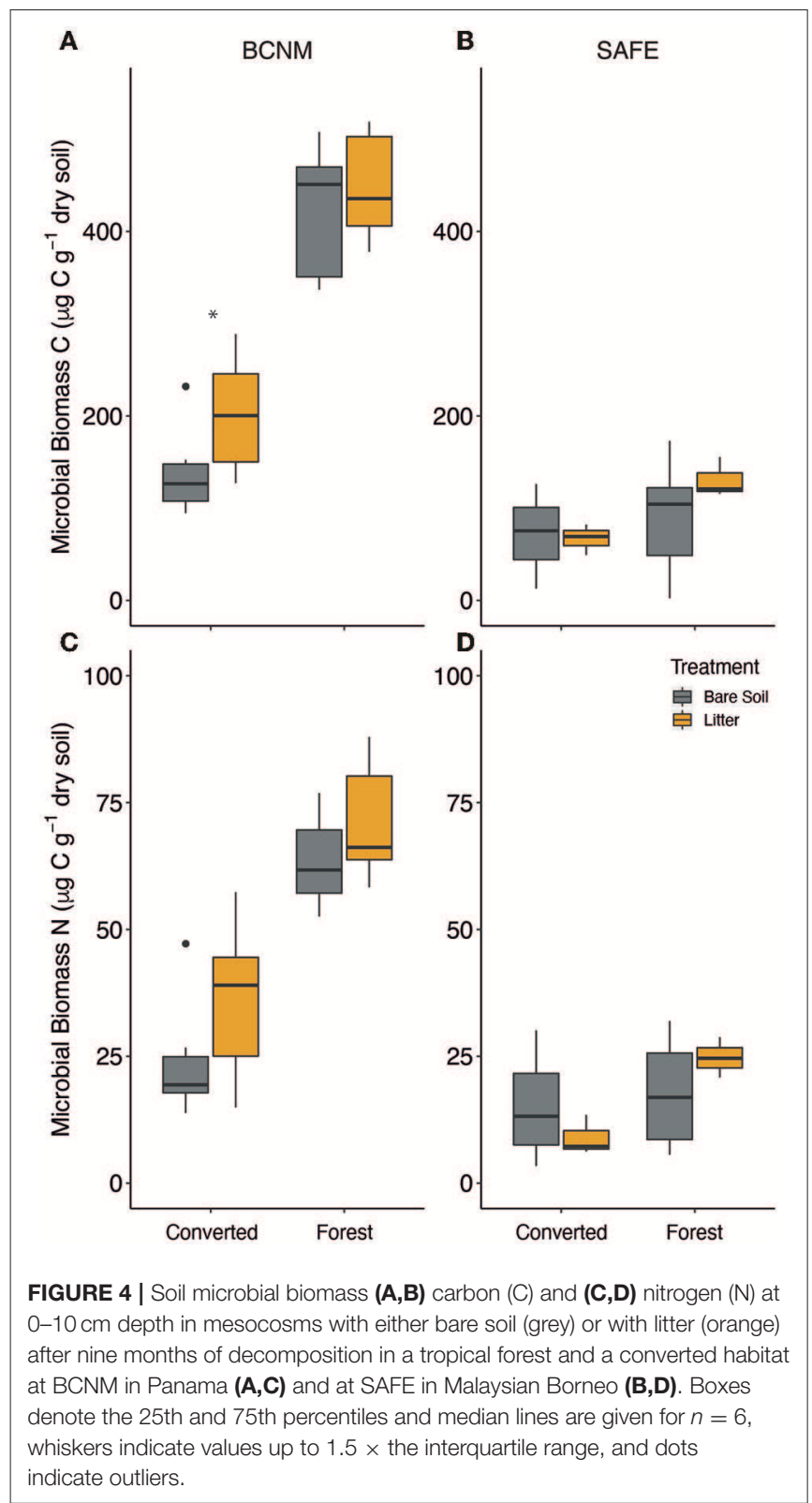

\section{DISCUSSION}

One of the most important changes during forest conversion and forest disturbance is the reduction in plant inputs, which has a substantial impact on soil C dynamics. Our study demonstrated that although decomposition rates differed markedly among litter types, introduced litter and forest litter had a similar influence on soil respiration and microbial biomass in two distinct tropical regions. Hence, the presence of litter per se was more important for maintaining soil processes than litter quality or diversity. Despite differences in soil properties and respiration rates between sites, habitat type had the greatest influence over litter decomposition and microbial activity due to the changes in the microclimate after deforestation. However, our experiment

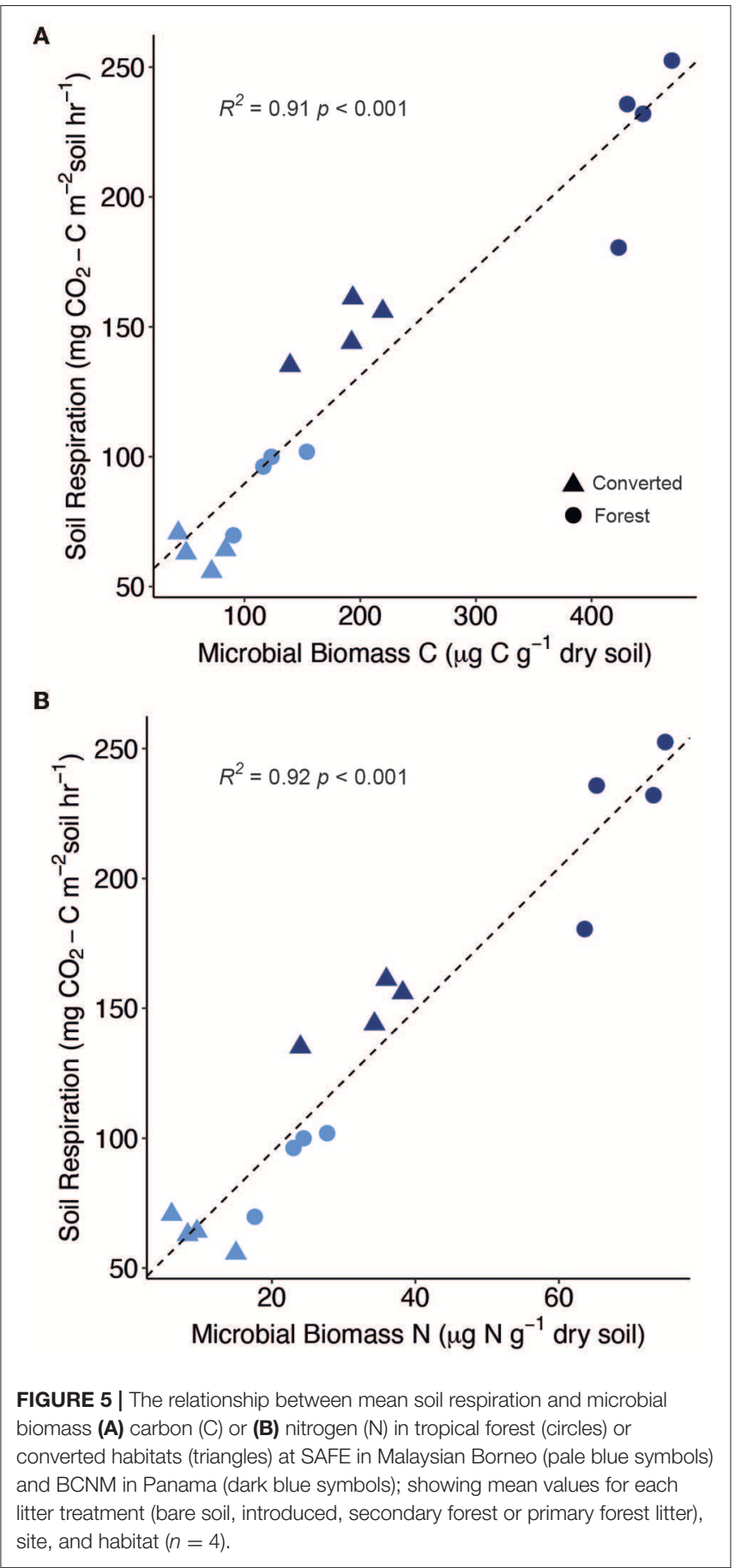

demonstrates the potential for litter inputs to maintain or rapidly restore soil processes in converted habitats.

\section{Habitat and Microclimate Influenced Decomposition Processes}

As expected, the distinct microclimate between forest and converted habitats had a substantial influence on litter decomposition and soil respiration, which supports our first hypothesis. At both sites, almost $80 \%$ of the litter had 
decomposed after nine months in the forested habitats but $<60 \%$ had decomposed in the converted habitats (Figure 2) and soil respiration was consistently higher in the forest habitats (Figure 3). A similar decline in decomposition in degraded tropical forests was also found in an experiment in China, in which open deforested land had significantly lower decomposition rates than old-growth and regenerating forests (Paudel et al., 2015) and similar patterns were found in Sabah (Both et al., 2017). The lower rates of decay and soil respiration in the converted habitats can be explained by a combination of lower soil nutrient content (Table 1), greater variation in soil temperature and water content (Figure 3), and lower soil microbial biomass (Figures 4, 5) compared to the forest habitat. Previous studies suggest that the presence of trees is essential for microbial activity (Salimon et al., 2004; Sotta et al., 2006; Schwendenmann et al., 2007; Vasconcelos et al., 2008), not only by providing substrate and shade, but also because plant litter acts as a buffer for variation in soil water and temperature at the surface (Sayer, 2006; Paudel et al., 2015). Tree cover in the converted habitats was sparse: the palms in the plantation in SAFE were planted between 6 and $9 \mathrm{~m}$ apart and trees were almost entirely absent in the converted habitat at BCNM. Hence, the lack of a closed canopy in the converted habitats likely resulted in rapid desiccation of the litter on the soil surface, providing a less stable environment for micro-organisms (Zhang and Zak, 1995; Yang et al., 2017) and slowing decomposition (Powers, 2004).

We observed similar responses of decomposition, soil respiration and microbial biomass to habitat type and litter inputs across sites on different continents, despite substantial differences in site characteristics. The distinct temporal patterns of soil respiration between sites can be largely explained by seasonality. BCNM experiences a strong dry season from January to April and accordingly, soil temperature in the converted habitat was much higher than in the forested habitat during particularly dry months, whereas soil water content was higher during the rainy season (Figure 3). Hence, both rapid desiccation during the dry season and waterlogging during the wet season may have slowed decomposition and reduced respiration in the converted habitat. By contrast, at SAFE the dry and wet seasons were not as distinctive but soil temperature in the converted habitats at SAFE was still consistently higher due to the lack of canopy cover, and although soil water content did not differ substantially from the forest habitat during the study, it was more variable in the converted habitat (Figure 3).

Besides the clear differences in habitat microclimate, the lower microbial biomass and nutrient availability of the converted habitats compared to the forest habitats is likely to have directly limited decomposition processes at both sites. In addition, faster mass loss at BCNM compared to SAFE can be explained by higher soil nutrient concentrations and microbial biomass at BCNM. Micro-organisms are essential for decomposition processes and decay rates are related to the abundance of organisms capable of breaking down the litter (Coûteaux et al., 1995), lower microbial biomass therefore often results in lower rates of decomposition (Singh and Gupta, 1977). Although we found no clear relationship between litter decay rates and microbial biomass across sites and habitats, we only measured microbial biomass at the end of the study, and there may have been a stronger relationship in the early stages of decomposition. Other studies have found that deforestation and the conversion to agriculture or grasslands significantly reduces soil $\mathrm{C}$, soil $\mathrm{N}$, and microbial biomass which in turn alter decomposition processes (Dinesh et al., 2003, 2004; Gomez-Acata et al., 2014). Another key difference between converted and forest habitats is the loss of faunal diversity in the former, especially invertebrate diversity (Fitzherbert et al., 2008). This could have further retarded litter decomposition because invertebrates play an essential role in the initial break-down of leaf litter, which increases the surface area and increases accessibility to soil microbes (Barajas-Guzmán and Alvarez-Sánchez, 2003; Ashford et al., 2013; García-Palacios et al., 2016).

\section{Litter Decay Rates Are Related to Litter Properties}

The properties and decay rates $(k)$ of forest litter were remarkably similar across the two sites on different continents and, as we hypothesised, the substantial differences in decomposition rates between the introduced and forest litters at both sites were explained by litter properties, in particular lignin content and the lignin: $\mathrm{N}$ ratio. The lignin content of litter is a good indicator of resource quality for microbial decomposers (Ordoñez et al., 2009; Hättenschwiler et al., 2011), and numerous studies demonstrate that litter with low lignin content or low lignin: $\mathrm{N}$ ratio decomposes rapidly (Hirobe et al., 2004; Kalbitz et al., 2006; Coq et al., 2011). In our study, litter $\mathrm{K}$ and, to a lesser extent, $\mathrm{P}$ were more important than $\mathrm{N}$ content in explaining decay rates. The introduced species had higher litter $\mathrm{P}$ and $\mathrm{K}$ content, which may be important for decomposition processes because tropical forests are widely acknowledged to be limited by $\mathrm{P}$ availability (Hättenschwiler and Jørgensen, 2010; Wright et al., 2011; Camenzind et al., 2018) and K can promote cellulose decomposition (Kaspari et al., 2008). Hence, the distinct properties of the introduced species litters, which were both characterised by low lignin: $\mathrm{N}$ ratios as well as high $\mathrm{P}$ and $\mathrm{K}$ concentrations (Table 3 ), could make them an attractive resource to microbial decomposers, resulting in much more rapid decomposition than the forest litter mixtures.

The similarity in litter properties, decay rates and mass loss of the two types of forest litters across both sites suggests that although litter diversity plays a key role in decomposition processes in tropical forests, species identity is less important. Recent work has found mixed evidence for non-additive effects in simple litter mixtures in tropical plantations, whereby only mixtures with the most functionally distinct litter types decomposed slower than expected (Kerdraon et al., 2019). A litter decomposition experiment in a 60-year old stand of the same study forest in BCNM found that natural mixed litter decomposed more slowly than a mixture of the three dominant pioneer species at the site, but was similar to a more diverse mixture with litter from three old-growth and three pioneer species (Laird-Hopkins et al., 2017). This suggests that the decomposition of litter from dominant tree species 
is not necessarily representative of decomposition processes in highly diverse tropical forests, and that non-additive effects may be more complex that in temperate systems, because microbial decomposers are adapted to functionally diverse litter inputs (Kerdraon et al., 2019). In our study, the oldgrowth and secondary forest mixtures had very similar litter characteristics and decay rates at both study sites, indicating that the secondary forest litter has the same functional characteristics and a similar influence on soil $\mathrm{C}$ dynamics as old-growth forest litter, despite differences in tree species composition. The striking similarities in litter properties and decay rates between forest habitats and between countries indicates that changes in tree species composition by forest disturbance may have little influence on soil $\mathrm{C}$ dynamics unless there is a fundamental shift in the functional characteristics of mixed plant litter inputs.

\section{Litter Inputs, Microbial Biomass, and Soil Function}

In contrast to our second hypothesis, and despite marked differences in litter properties and decay rates between introduced litter and forest litter, we observed no effect of litter type on soil respiration or microbial biomass in either habitat type at either site. Given that decay rates are driven by litter properties (Hättenschwiler et al., 2005; Cortez et al., 2007), we expected to detect differences in soil respiration measured directly above the decomposing litter mixtures. Although it is possible that the magnitude or duration of our litter treatments was insufficient to detect the effects of litter properties on soil respiration or microbial biomass, previous work has demonstrated clear responses of soil respiration to experimental litter mixtures over the same time-frame (Kerdraon et al., 2019). Furthermore, the differences in soil respiration and microbial biomass between mesocosms with or without litter demonstrate a measurable influence of litter presence (Figure 5). It is possible that the litter mixtures had a greater influence on microbial biomass during the early stages of decomposition; however, soil samples taken from an additional set of mesocosms after six months (SAFE only, data not shown) also showed no differences in microbial biomass among litter treatments, and soil respiration rates did not differ consistently among litter types during the first three months of the study (Supplementary Figure S1).

The importance of aboveground litter inputs for maintaining key soil processes (Sayer, 2006) is demonstrated in our study by the higher soil respiration with litter inputs and the decline in microbial biomass $\mathrm{C}$ and $\mathrm{N}$ in the forest habitats after nine months of litter exclusion at both sites (Figure 4). Given the low plant inputs to the soil in the converted habitats, we hypothesised that the response of soil respiration and microbial biomass to the litter treatments would be greater than in the forest habitats. We found little evidence to support this hypothesis as microbial biomass in the converted habitat only responded to litter inputs at BCNM, and the response of soil respiration was lower in converted habitats. Soil organic matter content is important for sustaining microbial biomass and activity (Reeves,
1997; García-Orenes et al., 2010; Xu et al., 2018) and the lower soil C content we measured at SAFE (Table 1) likely explains why soil respiration and microbial biomass were lower in both habitats at SAFE compared to BCNM, and underpins the strong relationship between microbial biomass and soil respiration (Figure 5). Although soil respiration increased with litter inputs in the converted habitats at both sites (Figure 3), microbial biomass did not respond to litter inputs in the converted habitat at SAFE (Figure 4). It is therefore conceivable that soil microbial communities in the oil palm plantations were so substrate-limited that our litter treatments were only sufficient to stimulate activity and turnover, but not to boost growth. Although beyond the scope of the present study, shifts in microbial communities and substrate use efficiency in response to altered plant inputs and microclimate in the converted sites may explain the differences between habitats as well as the similarities across sites.

Previous studies at SAFE have noted that specialised forest microbial communities were missing from oil palm plantations (Lee-Cruz et al., 2013; Van Straaten et al., 2015), which could indicate that the soil microbes present in the oil palm habitat may not be capable of processing more complex and diverse forest leaf litter. However, microbial biomass did not increase with the addition of any litter type, including oil palm litter, which indicates that soil microbial communities in oil palm plantations are constrained by more than just litter quality. In addition, herbicide application to prevent understorey plant growth in the oil palm plantations could have also played a role by eliminating some microbial taxa (Perucci et al., 2000) and further reducing plant inputs. By contrast, the soil microbial community in the converted habitat at BCNM was able to respond to greater substrate availability by increasing both activity (soil respiration) and growth (biomass), suggesting that inputs from herbaceous plants have helped maintain soil functioning, despite minimal aboveground litterfall. Management of oil palm plantations in other areas includes soil amendment with empty fruit bunches, a waste product from palm oil extraction, which improves soil fertility and functioning (Tao et al., 2018). In our study, the strong influence of aboveground litter on soil respiration and microbial biomass, regardless of habitat, species diversity, or litter type, is encouraging because it suggests that soil functioning in converted habitats could be maintained to a certain degree by simple litter inputs (Pauli et al., 2014; Teuscher et al., 2016).

\section{CONCLUSIONS}

Our study highlights the importance of aboveground litter inputs for maintaining soil processes in disturbed forests and converted habitats. Our findings reveal a disconnect between the substantial influence of litter properties on decomposition rates and the much smaller effect of distinct litter types on soil respiration and microbial biomass. Overall, our litter transplant experiments showed the same responses of forest and converted habitats to litter inputs on two different continents, and remarkably similar patterns of litter decomposition. Whereas, the altered microclimate in the converted habitats explained the lower rates 
of decomposition and soil respiration compared to the forest habitats, the response of microbial activity to litter inputs in the converted habitats suggests that the presence of leaf litter as a source of organic matter is essential to maintain soil processes in degraded forest ecosystems.

\section{DATA AVAILABILITY STATEMENT}

The datasets generated for this study are available on request to the corresponding author and will be deposited with the Environmental Information Data Centre (EIDC).

\section{AUTHOR CONTRIBUTIONS}

EJS and EMS conceived the experiment. EJS, DK, JD, and BC-T designed the work. AC, NM, BC-T, AW, LB, and DK performed the field measurements and laboratory analyses. EJS, JD, and DK analysed and interpreted the data and wrote the manuscript. All authors have contributed to interpretation of results.

\section{FUNDING}

This research was funded by the Natural Environment Research Council (NERC), UK grant numbers NE/K016164/1 and NE/K016164/2 under the Human-modified Tropical

\section{REFERENCES}

Adachi, M., Bekku, Y. S., Rashidah, W., Okuda, T., and Koizumi, H. (2006). Differences in soil respiration between different tropical ecosystems. Appl. Soil Ecol. 34, 258-265. doi: 10.1016/j.apsoil.2006.01.006

Armenteras, D., Espelta, J. M., Rodríguez, N., and Retana, J. (2017). Deforestation dynamics and drivers in different forest types in Latin America: three decades of studies (1980-2010). Global Environ. Change 46, 139-147. doi: 10.1016/j.gloenvcha.2017.09.002

Ashford, O. S., Foster, W. A., Turner, B. L., Sayer, E. J., Sutcliffe, L., and Tanner, E. V. J. (2013). Litter manipulation and the soil arthropod community in a lowland tropical rainforest. Soil Biol. Biochem. 62, 5-12. doi: $10.1016 /$ j.soilbio.2013.03.001

Attiwill, P. M., and Adams, M. A. (1993). Nutrient cycling in forests. New Phytol. 124, 561-582. doi: 10.1111/j.1469-8137.1993.tb03847.x

Ayres, E., Steltzer, H., Berg, S., and Wall, D. H. (2009). Soil biota accelerate decomposition in high-elevation forests by specializing in the breakdown of litter produced by the plant species above them. J. Ecol. 97, 901-912. doi: 10.1111/j.1365-2745.2009.01539.x

Barajas-Guzmán, G., and Alvarez-Sánchez, J. (2003). The relationships between litter fauna and rates of litter decomposition in a tropical rain forest. Appl. Soil Ecol. 24, 91-100. doi: 10.1016/S0929-1393(03)00069-6

Bates, D. M., Mächler, M., Bolker, B., and Walker, S. (2014). Fitting linear mixedeffects models using lme4. J. Stat. Softw. 67, 1-48. doi: 10.18637/jss.v067.i01

Both, S., Elias, D. M. O., Kritzler, U. H., Ostle, N. J., and Johnson, D. (2017). Land use not litter quality is a stronger driver of decomposition in hyperdiverse tropical forest. Ecol. Evol. 7, 9307-9318. doi: 10.1002/ece3.3460

Bruun, T. B., De Neergaard, A., Lawrence, D., and Ziegler, A. D. (2009). Environmental consequences of the demise in swidden cultivation in Southeast Asia: carbon storage and soil quality. Human Ecol. 37, 375-388. doi: 10.1007/s10745-009-9257-y

Camenzind, T., Hättenschwiler, S., Treseder, K. K., Lehmann, A., and Rillig, M. C. (2018). Nutrient limitation of soil microbial processes in tropical forests. Ecol. Monogr. 88, 4-21. doi: 10.1002/ecm.1279
Forests Programme. The APC was funded by the Natural Environment Research Council (NERC) UK through Lancaster University.

\section{ACKNOWLEDGEMENTS}

We are grateful to A. Ryan, L. Lopez-Sangil, J. Crawford, and A. Birkett for laboratory support. We thank the NERC LOMBOK field assistants for their help, especially Lawlina Mansul and Norlizeh Tausong. We thank G. Reynolds the South East Asia Rainforest Research Partnership (SEARRP), R. Ewers and The Stability of Altered Forests Ecosystems Project (SAFE), The Maliau Basin Management Committee (MBMC), and the Sabah Biodiversity Council, Malaysia, for their support in obtaining permits and research permissions. Samples in Malaysia were collected under SaBC access licence number JKM/MBS.10002/2(381) to EMS and DK, and Project No. 129 under MBMC. We also thank the Smithsonian Tropical Research Institute for their support, especially Melissa Cano.

\section{SUPPLEMENTARY MATERIAL}

The Supplementary Material for this article can be found online at: https://www.frontiersin.org/articles/10.3389/ffgc.2019. 00090/full\#supplementary-material

Coûteaux, M. M., Bottner, P., and Berg, B. (1995). Litter decomposition climate and litter quality. Trends Ecol. Evol. 10, 63-66. doi: 10.1016/S0169-5347(00)88978-8

Coq, S., Weigel, J., Butenschoen, O., Bonal, D., and Hättenschwiler, S. (2011). Litter composition rather than plant presence affects decomposition of tropical litter mixtures. Plant Soil 343, 273-286. doi: 10.1007/s11104-011-0717-y

Cortez, J., Garnier, E., Pérez-Harguindeguy, N., Debussche, M., and Gillon, D. (2007). Plant traits, litter quality and decomposition in a Mediterranean oldfield succession. Plant Soil 296, 19-34. doi: 10.1007/s11104-007-9285-6

Crawley, M. J. (2007). The $R$ Book. Chichester: John Wiley \& Sons. doi: 10.1002/9780470515075

Dechert, G., Veldkamp, E., and Anas, I. (2004). Is soil degradation unrelated to deforestation? Examining soil parameters of land use systems in upland Central Sulawesi, Indonesia. Plant Soil. 265, 197-209. doi: 10.1007/s11104-005-0885-8

Dent, D. H., Dewalt, S. J., and Denslow, J. S. (2013). Secondary forests of central Panama increase in similarity to old-growth forest over time in shade tolerance but not species composition. J. Veg. Sci. 24, 530-542. doi: $10.1111 /$ j.1654-1103.2012.01482.x

Dinesh, R., Chaudhuri, S. G., Ganeshamurthy, A. N., and Dey, C. (2003). Changes in soil microbial indices and their relationships following deforestation and cultivation in wet tropical forests. Appl. Soil Ecol. 24, 17-26. doi: 10.1016/S0929-1393(03)00070-2

Dinesh, R., Ghoshal Chaudhuri, S., and Sheeja, T. E. (2004). Soil biochemical and microbial indices in wet tropical forests: effects of deforestation and cultivation. J. Plant Nutr. Soil Sci. 167, 24-32. doi: 10.1002/jpln.200321254

Don, A., Schumacher, J., and Freibauer, A. (2011). Impact of tropical land-use change on soil organic carbon stocks - a meta-analysis. Glob. Chang. Biol. 17, 1658-1670. doi: 10.1111/j.1365-2486.2010.02336.x

Ewers, R. M., Didham, R. K., Fahrig, L., Ferraz, G., Hector, A., Holt, R. D., et al. (2011). A large-scale forest fragmentation experiment: the Stability of Altered Forest Ecosystems Project. Philos. Trans. R. Soc. Lond. B Biol. Sci. 366, 3292-3302. doi: 10.1098/rstb.201 1.0049

Fanin, N., Hättenschwiler, S., Barantal, S., Schimann, H., and Fromin, N. (2011). Does variability in litter quality determine soil microbial 
respiration in an Amazonian rainforest? Soil Biol. Biochem. 43, 1014-1022. doi: 10.1016/j.soilbio.2011.01.018

Fitzherbert, E. B., Struebig, M. J., Morel, A., Danielsen, F., Brühl, C. A., Donald, P. F., et al. (2008). How will oil palm expansion affect biodiversity? Trends Ecol. Evol. 23, 538-545. doi: 10.1016/j.tree.2008.06.012

García-Orenes, F., Guerrero, C., Roldán, A., Mataix-Solera, J., Cerdà, A., Campoy, M., et al. (2010). Soil microbial biomass and activity under different agricultural management systems in a semiarid Mediterranean agroecosystem. Soil Tillage Res. 109, 110-115. doi: 10.1016/j.still.2010. 05.005

García-Palacios, P., Mckie, B. G., Handa, I. T., Frainer, A., and Hättenschwiler, S. (2016). The importance of litter traits and decomposers for litter decomposition: a comparison of aquatic and terrestrial ecosystems within and across biomes. Funct. Ecol. 30, 819-829. doi: 10.1111/1365-2435. 12589

Global Forest Watch (2018). World Resources Institute. Available online at: www. globalforestwatch.org (accessed July 15, 2019).

Gomez-Acata, E. S., Valencia-Becerril, I., Valenzuela-Encinas, C., VelasquezRodriguez, A. S., Navarro-Noya, Y. E., Montoya-Ciriaco, N., et al. (2014). Deforestation and cultivation with maize (Zea mays L.) has a profound effect on the bacterial community structure in soil. L. Degrad. Dev. 1130, 1122-1130. doi: 10.1002/ldr.2328

Gougoulias, C., Clark, J. M., and Shaw, L. J. (2014). The role of soil microbes in the global carbon cycle: tracking the below-ground microbial processing of plantderived carbon for manipulating carbon dynamics in agricultural systems. J. Sci. Food Agric. 94, 2362-2371. doi: 10.1002/jsfa.6577

Guillaume, T., Damris, M., and Kuzyakov, Y. (2015). Losses of soil carbon by converting tropical forest to plantations: erosion and decomposition estimated by $\delta^{13}$ C. Glob. Chang. Biol. 21, 3548-3560. doi: 10.1111/gcb.12907

Handa, I. T., Aerts, R., Berendse, F., Berg, M. P., Bruder, A., Butenschoen, O., et al. (2014). Consequences of biodiversity loss for litter decomposition across biomes. Nature 509, 218-221. doi: 10.1038/nature13247

Hansen, M. C., Potapov, P. V., Moore, R., Hancher, M., Turubanova, S. A. A., Tyukavina, A., et al. (2013). High-resolution global maps of 21stcentury forest cover change. Science 342, 850-853. doi: 10.1126/science.1 244693

Hättenschwiler, S., Coq, S., Barantal, S., and Handa, I. T. (2011). Leaf traits and decomposition in tropical rainforest: revisiting some commonly held views and towards a new hypothesis. New Phytol. 950-965. doi: 10.1111/j.1469-8137.2010.03483.x

Hättenschwiler, S., and Jørgensen, H. B. (2010). Carbon quality rather than stoichiometry controls litter decomposition in a tropical rain forest. J. Ecol. 98, 754-763. doi: 10.1111/j.1365-2745.2010.01671.x

Hättenschwiler, S., Tiunov, A., and Scheu, S. (2005). Biodiversity and litter deomposition in terrestrial ecosystems. Annu. Rev. Ecol. Evol. 36, 191-218. doi: 10.1146/annurev.ecolsys.36.112904.151932

Hirobe, M., Sabang, J., Bhatta, B. K., and Takeda, H. (2004). Leaf-litter decomposition of 15 tree species in a lowland tropical rain forest in Sarawak: decomposition rates and initial litter chemistry. J. Forest Res. 9, 341-346. doi: 10.1007/s10310-004-0087-x

Houghton, R. A. (2012). Carbon emissions and the drivers of deforestation and forest degradation in the tropics. Curr. Opin. Environ. Sustain. 4, 597-603. doi: 10.1016/j.cosust.2012.06.006

Isbell, F., Calcagno, V., Hector, A., Connolly, J., Harpole, W. S., Reich, P. B., et al. (2011). High plant diversity is needed to maintain ecosystem services. Nature 477, 199-202. doi: 10.1038/nature 10282

Jones, D. L., and Willett, V. B. (2006). Experimental evaluation of methods to quantify dissolved organic nitrogen (DON) and dissolved organic carbon (DOC) in soil. Soil Biol. Biochem. 38, 991-999. doi: 10.1016/j.soilbio.2005.08.012

Kalbitz, K., Kaiser, K., Bargholz, J., and Dardenne, P. (2006). Lignin degradation controls the production of dissolved organic matter in decomposing foliar litter. Eur. J. Soil Sci. 57, 504-516. doi: 10.1111/j.1365-2389.2006.00797.x

Kaspari, M., Garcia, M. N., Harms, K. E., Santana, M., Wright, S. J., and Yavitt, J. B. (2008). Multiple nutrients limit litterfall and decomposition in a tropical forest. Ecol. Lett. 11, 35-43. doi: 10.1111/j.1461-0248.2007.01124.x

Kerdraon, D., Drewer, J., Castro, B., Wallwork, A., Hall, J. S., and Sayer, E. J. (2019). Litter traits of native and non-native tropical trees influence soil carbon dynamics in timber plantations in Panama. Forests 10, 209 doi: 10.3390/f10030209

Laird-Hopkins, B. C., Bréchet, L. M., Trujillo, B. C., and Sayer, E. J. (2017). Tree functional diversity affects litter decomposition and arthropod community composition in a tropical forest. Biotropica 49, 903-911. doi: 10.1111/btp. 12477

Lal, R. (2005). Forest soils and carbon sequestration. For. Ecol. Manage. 220, 242-258. doi: 10.1016/j.foreco.2005.08.015

Laurance, W. F., Sayer, J., and Cassman, K. G. (2014). Agricultural expansion and its impacts on tropical nature. Trends Ecol. Evol. 29, 107-116. doi: 10.1016/j.tree.2013.12.001

Le Quéré, C., Andrew, R. M., Friedlingstein, P., Sitch, S., Hauck, J., Pongratz, J., et al., (2018). Global Carbon Budget 2018. Earth Syst. Sci. Data 10, 2141-2194. doi: 10.5194/essd-2017-123-AC6

Lee-Cruz, L., Edwards, D. P., Tripathi, B. M., and Adams, J. M. (2013). Impact of logging and forest conversion to oil palm plantations on soil bacterial communities in borneo. Appl. Environ. Microbiol. 79, 7290-7297. doi: 10.1128/AEM.02541-13

Lorenzo, L., Pérez-Harguindeguy, N., Casanoves, F., and de Oliveira, A. A. (2014). Recovering from forest-to-pasture conversion: leaf decomposition in Central Amazonia, Brazil. J. Trop. Ecol. 30, 93-96. doi: 10.1017/S02664674130 00771

Malhi, Y. (2010). The carbon balance of tropical forest regions, 1990-2005. Curr. Opin. Environ. Sustain. 2, 237-244. doi: 10.1016/j.cosust.2010.08.002

Marichal, R., Mathieu, J., Couteaux, M. M., Mora, P., Roy, J., and Lavelle, P. (2011). Earthworm and microbe response to litter and soils of tropical forest plantations with contrasting C:N:P stoichiometric ratios. Soil Biol. Biochem. 43, 1528-1535. doi: 10.1016/j.soilbio.2011.04.001

Olson, J. S. (1963). Energy storage and the balance of producers and decomposers in ecological systems. Ecology 44, 322-331. doi: 10.2307/1932179

Ordoñez, J. C., Van Bodegom, P. M., Witte, J. P. M., Wright, I. J., Reich, P. B., and Aerts, R. (2009). A global study of relationships between leaf traits, climate and soil measures of nutrient fertility. Glob. Ecol. Biogeogr. 18, 137-149. doi: 10.1111/j.1466-8238.2008.00441.x

Pan, Y., Birdsey, R. A., Fang, J., Houghton, R., Kauppi, P. E., Kurz, W. A., et al. (2011). A large and persistent carbon sink in the world's forests. Science 333, 988-993. doi: 10.1126/science.1201609

Paudel, E., Dossa, G. G. O., Blécourt, M., de, Beckschäfer, P., Xu, J., and Harrison, R. D. (2015). Quantifying the factors affecting leaf litter decomposition across a tropical forest disturbance gradient. Ecosphere 6, 1-20. doi: 10.1890/ES15-00112.1

Pauli, N., Donough, C., Oberthür, T., Cock, J., Verdooren, R., Abdurrohim, G., et al. (2014). Changes in soil quality indicators under oil palm plantations following application of 'best management practices' in a fouryear field trial. Agric. Ecosyst. Environ. 195, 98-111. doi: 10.1016/j.agee.2014. 05.005

Pendrill, F., Persson, U. M., Godar, J., Kastner, T., Moran, D., Schmidt, S., et al. (2019). Agricultural and forestry trade drives large share of tropical deforestation emissions. Glob Environ Change 56, 1-10. doi: 10.1016/j.gloenvcha.2019.03.002

Perucci, P., Dumontet, S., Bufo, S. A., Mazzatura, A., and Casucci, C. (2000). Effects of organic amendment and herbicide treatment on soil microbial biomass. Biol. Fertil. Soils 32, 17-23. doi: 10.1007/s003740000207

Pinheiro, J. C., and Bates, D. M. (2000). Mixed-Effects Models in S and S-PLUS. New York, NY: Springer. doi: 10.1007/978-1-4419-0318-1

Powers, J. S. (2004). Changes in Soil Carbon and Nitrogen after Contrasting Land-use Transitions in Northeastern Costa Rica. Ecosystems 7, 134-146. doi: 10.1007/s10021-003-0123-2

Pumpanen, J., Kolari, P., Ilvesniemi, H., Minkkinen, K., Vesala, T., Niinistö, S., et al. Hari, P. (2004). Comparison of different chamber techniques for measuring soil CO2efflux. Agric. For. Meteorol. 123, 159-176. doi: 10.1016/j.agrformet.2003.12.001

R Core Team (2018). R: A Language and Environment for Statistical Computing. Vienna: R Foundation for Statistical Computing. Available online at: https:// www.R-project.org/

Reeves, D. W. (1997). The role of soil organic matter in maintaining soil quality in continuous cropping systems. Soil Tillage Res. 43, 131-167. doi: 10.1016/S0167-1987(97)00038-X 
Reynolds, G., Payne, J., Sinun, W., Mosigil, G., and Walsh, R. P. D. (2011). Changes in forest land use and management in Sabah, Malaysian Borneo, 1990-2010, with a focus on the Danum Valley region. Philos. Trans. R. Soc. B Biol. Sci. 366, 3168-3176. doi: 10.1098/rstb.2011.0154

Riutta, T., Malhi, Y., Kho, L. K., Marthews, T. R., Huaraca Huasco, W., Khoo, M., et al. (2018). Logging disturbance shifts net primary productivity and its allocation in Bornean tropical forests. Glob. Chang. Biol. 24, 1-16. doi: $10.1111 /$ gcb.14068

Salimon, C. I., Davidson, E. A., Victoria, R. L., and Melo, W. F. (2004). $\mathrm{CO}_{2}$ flux from soil in pastures and forests in southwestern Amazonia. Glob. Chang. Biol. 10, 833-843. doi: 10.1111/j.1529-8817.2003.00776.x

Sayer, E. J. (2006). Using experimental manipulation to assess the roles of leaf litter in the functioning of forest ecosystems. Biol. Rev. Camb. Philos. Soc. 81, 1-31. doi: $10.1017 /$ S1464793105006846

Sayer, E. J., and Tanner, E. V. J. (2010). Experimental investigation of the importance of litterfall in lowland semi-evergreen tropical forest nutrient cycling. J. Ecol. 98, 1052-1062. doi: 10.1111/j.1365-2745.2010.01680.x

Scharlemann, J. P. W., Tanner, E. V. J., Hiederer, R., and Kapos, V. (2014). Global soil carbon: understanding and managing the largest terrestrial carbon pool. Carbon Manage. 5, 81-91. doi: 10.4155/cmt.13.77

Schwendenmann, L., Pendall, E., and Potvin, C. (2007). "Surface soil organic carbon pools, mineralization and $\mathrm{CO}(2)$ efflux rates under different landuse types in Central Panama," in Stability of Tropical Rainforest Margins. Environmental Science and Engineering, eds T. Tscharntke, C. Leuschner, M. Zeller, E. Guhardja, and A. Bidin (Berlin; Heidelberg: Springer), 109-131.

Singh, J. S., and Gupta, S. R. (1977). Plant decomposition and soil respiration in terrestrial ecosystems. Bot. Rev. 43, 449-528. doi: 10.1007/BF02860844

Sotta, E. D., Veldkamp, E., Guimarães, B. R., Paixão, R. K., Ruivo, M. L. P., and Almeida, S. S. (2006). Landscape and climatic controls on spatial and temporal variation in soil CO2 efflux in an Eastern Amazonian Rainforest, Caxiuanã, Brazil. For. Ecol. Manage. 237, 57-64. doi: 10.1016/j.foreco.2006.09.027

Stockmann, U., Adams, M. A., Crawford, J. W., Field, D. J., Henakaarchchi, N., Jenkins, M., et al. (2013). The knowns, known unknowns and unknowns of sequestration of soil organic carbon. Agric. Ecosyst. Environ. 164, 80-99. doi: 10.1016/j.agee.2012.10.001

Swaine, M. D., and Whitmore, T. C. (1988). On the definition of ecological species groups in tropical rain forests. Vegetation 75, 81-86. doi: 10.1007/BF00044629

Tao, H. H., Snaddon, J. L., Slade, E. M., Henneron, L., Caliman, J. P., and Willis, K. J. (2018). Application of oil palm empty fruit bunch effects on soil biota and functions: a case study in Sumatra, Indonesia. Agric. Ecosyst. Environ. 256, 105-113. doi: 10.1016/j.agee.2017.12.012

Tesfaye, M. A., Bravo, F., Ruiz-Peinado, R., Pando, V., and Bravo-Oviedo, A. (2016). Impact of changes in land use, species and elevation on soil organic carbon and total nitrogen in Ethiopian Central Highlands. Geoderma 261, 70-79. doi: 10.1016/j.geoderma.2015.06.022

Teuscher, M., Gérard, A., Brose, U., Buchori, D., Clough, Y., Ehbrecht, M., et al. (2016). Experimental biodiversity enrichment in oil-palm-dominated landscapes in Indonesia. Front. Plant Sci. 7:1538. doi: 10.3389/fpls.2016.01538

Van Der Heijden, M. G. A., Bardgett, R. D., and Van Straalen, N. M. (2008). The unseen majority: soil microbes as drivers of plant diversity and productivity in terrestrial ecosystems. Ecol. Lett. 11, 296-310. doi: 10.1111/j.1461-0248.2007.01139.x

Van Soest, P. V., Robertson, J. B., and Lewis, B. A. (1991). Methods for dietary fiber, neutral detergent fiber, and nonstarch polysaccharides in relation to animal nutrition. J. Dairy Sci. 74, 3583-3597. doi: 10.3168/jds.S0022-0302(91)78551-2

Van Straaten, O., Corre, M. D., Wolf, K., Tchienkoua, M., Cuellar, E., Matthews, R. B., et al. (2015). Conversion of lowland tropical forests to tree cash crop plantations loses up to one-half of stored soil organic carbon. Proc. Natl. Acad. Sci. U.S.A. 112, 9956-9960. doi: 10.1073/pnas.1504628112

Vance, E. D., Brookes, P. C., and Jenkinson, D. S. (1987). An extraction method for measuring soil microbial biomass C. Soil Biol. Biochem. 19, 703-707. doi: 10.1016/0038-0717(87)90052-6

Vasconcelos, S. S., Zarin, D. J., Araújo, M. M., Rangel-Vasconcelos, L. G. T., de Carvalho, C. J. R., Staudhammer, C. L., et al. (2008). Effects of seasonality, litter removal and dry-season irrigation on litterfall quantity and quality in eastern Amazonian forest regrowth, Brazil. J. Trop. Ecol. 24, 27-38. doi: 10.1017/S0266467407004580

Vitousek, P. M. (1984). Litterfall, nutrient cycling, and nutrient limitation in tropical forests. Ecology 65, 285-298. doi: 10.2307/1939481

Wilcove, D. S., Giam, X., Edwards, D. P., Fisher, B., and Koh, L. P. (2013). Navjot's nightmare revisited: logging, agriculture, and biodiversity in Southeast Asia. Trends Ecol. Evol. 28, 531-540. doi: 10.1016/j.tree.2013.04.005

Wright, S. J. (2005). Tropical forests in a changing environment. Trends Ecol. Evol. 20, 553-560. doi: 10.1016/j.tree.2005.07.009

Wright, S. J., Yavitt, J. B., Wurzburger, N., Turner, B. L., Tanner, E. V. J., Sayer, E. J., et al. (2011). Potassium, phosphorus, or nitrogen limit root allocation, tree growth, or litter production in a lowland tropical forest. Ecology 92, 1616-1625. doi: 10.1890/10-1558.1

Xu, S., Li, P., Sayer, E. J., Zhang, B., Wang, J., Qiao, C., et al. (2018). Initial soil organic matter content influences the storage and turnover of litter, root and soil carbon in grasslands. Ecosystems 21, 1377-1389. doi: 10.1007/s10021-018-0227

Yang, Y., Geng, Y., Zhou, H., Zhao, G., and Wang, L. (2017). Effects of gaps in the forest canopy on soil microbial communities and enzyme activity in a Chinese pine forest. Pedobiologia 61, 51-60. doi: 10.1016/j.pedobi.2017.03.001

Zhang, Q., and Zak, J. C. (1995). Effects of gap size on litter decomposition and microbial activity in a subtropical forest. Ecology 7, 2196-2204. doi: $10.2307 / 1941693$

Conflict of Interest: The authors declare that the research was conducted in the absence of any commercial or financial relationships that could be construed as a potential conflict of interest.

Copyright (c) 2020 Kerdraon, Drewer, Chung, Majalap, Slade, Bréchet, Wallwork, Castro-Trujillo and Sayer. This is an open-access article distributed under the terms of the Creative Commons Attribution License (CC BY). The use, distribution or reproduction in other forums is permitted, provided the original author(s) and the copyright owner(s) are credited and that the original publication in this journal is cited, in accordance with accepted academic practice. No use, distribution or reproduction is permitted which does not comply with these terms. 